\title{
The use of fire in the environmental rehabilitation on the sites of a former refugee camp at Benaco, Tanzania
}

URS BLOESCH

Keywords: Fire ecology; fire management; savanna dynamics; Tanzania. $\quad$ FDK 181.43 : 43 : 935.4 : (678)

Abstract: The enormous wood requirements of about 450000 Rwandan refugees in northwestern Tanzania led to the depletion of the wood resources in the surrounding savannas in an area of about $500 \mathrm{~km}^{2}$. The natural regeneration of the woody plants was endangered by frequent fierce late dry-season fires. Since total fire exclusion of the vast area was not feasible, early-burning was prescribed which is less destructive to woody regeneration than the hotter late burns and which prevents the more destructive late dry-season fires. The techniques of controlled burning are explained.

\section{Introduction}

On April $22^{\text {nd }}, 1994$, during the civil war in Rwanda, more than 400000 Rwandan refugees crossed the Tanzanian border at Rusumo in northwestern Tanzania in just two days. A mass exodus on this scale within such a short period of time is probably unique so far. The refugees settled in an area with a low population density (only about 50 people per $\mathrm{km}^{2}$ ) in the vicinity of a water dam, near the village of Kasulo $\left(2^{\circ} 30^{\prime} \mathrm{S}, 30^{\circ} 51^{\prime} \mathrm{E}\right)$ about $20 \mathrm{~km}$ from Rusumo (see figure 1). The small village of Kasulo with less than one thousand inhabitants became, within a few days, the second largest agglomeration of Tanzania, thereby quadrupling the population of the Ngara District. The

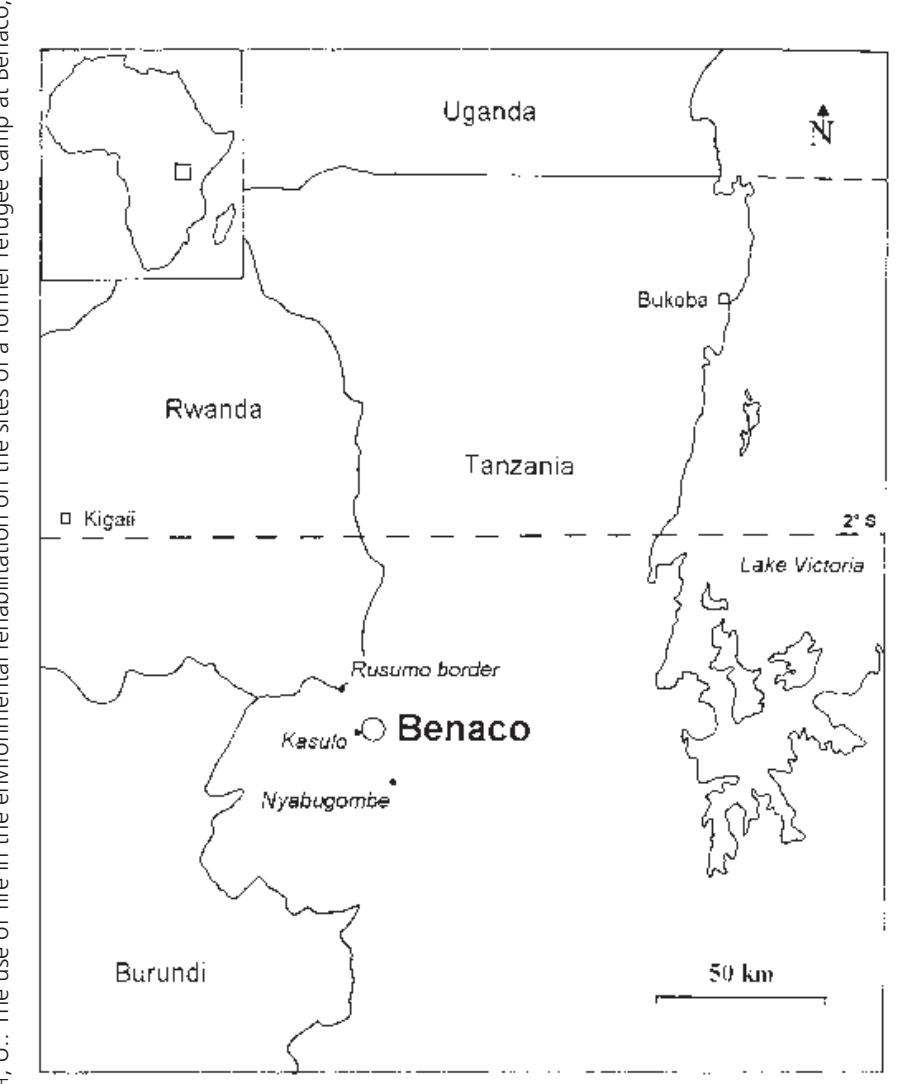

Figure 1: Location of Benaco.

Abbildung 1: Lage von Benaco.
Abstract: Der enorme Holzbedarf von rund 450000 rwandischen Flüchtlingen im Nordosten Tansanias führte zur Abholzung der umliegenden Savannen auf einem Gebiet von rund $500 \mathrm{~km}^{2}$. Die natürliche Wiederbestockung wurde erschwert durch häufige, destruktive Spätfeuer (gegen Ende der Trockenzeit). Da das Gebiet zu weitläufig ist, um Brände gänzlich ausschliessen zu können, wurden gezielt kontrollierte Frühfeuer (zu Beginn der Trockenzeit) eingesetzt. Frühfeuer sind weniger schädlich für die Holzverjüngung (tiefere Temperaturen) als Spätfeuer und sie verhindern Spätfeuer zwangsläufig im gleichen Jahr. Die Technik des kontrollierten Abbrennens wird erklärt.

refugee camp was called Benaco after a road constructing company, which had formerly been based in this area.

Benaco lies in a savanna landscape characterised by its smooth rolling hills between $1500 \mathrm{~m}$ and $1700 \mathrm{~m}$ a.s.l. (see figure 2). As in many regions of East Africa near the equator rainfall is bimodal. The mean annual rainfall is about $900 \mathrm{~mm}$ with a main dry season from May to August. The mean annual temperature is about $21^{\circ} \mathrm{C}$. The climate type in the Köppen system is Aw (KöPPEN 1931). Ferralsols occur on the prevailing gentle to moderate slopes, while Vertisols are found in valley bottoms and Leptosols are restricted to the few stony hillsides (FAO-UnesCo 1988)

Before the arrival of the refugees, relative densely wooded savannas (tree and shrub cover ${ }^{1}$ between $20 \%$ and $40 \%$ ) prevailed in the area of Benaco (vegetation types according to the Yangambi classification, see SCIENTIFIC COUNCIL FOR AfRICA SOUTH OF THE SAHARA 1956). The highest growing stock of 40 to $50 \mathrm{~m}^{3} /$ ha was found in savanna woodland type with almost pure stands of Acacia polyacantha subsp. campylacantha (nomenclature: TroupIN 1978, 1983, 1985, 1988). However, this savanna type is limited to valley bottoms and gallery forests along temporary watercourses. The average growing stock for all savanna types was estimated to be about $30 \mathrm{~m}^{3} / \mathrm{ha}$. Broadleafed trees were more abundant than the fine-leafed Acacias. Table 1 lists the most frequently occurring species.

The number of refugees increased eventually to about 450000 . Although, later on, the number of refugees in the Benaco camp was reduced by opening new camps, about 350000 refugees remained concentrated in camps of Greater Benaco (only a few kilometres away from each other), a concentration that had a large impact on the environment and the socio-economic situation of the local population (e.g. increased food prices, scarcity of wood, increased criminality).

Immediately after their arrival, the refugees cut wood for the construction of shelters and gathered fuelwood in the vicinity of the camps for their energy requirements. As time went by the need for construction wood decreased but energy demand was permanent (primarily cooking, but also for heating, lighting, brewing). Therefore, the cutting of fuel-

${ }^{1}$ For our purpose we define the canopy cover as the sum of the vertical crown projections assuming that the crowns are not light permeable. 


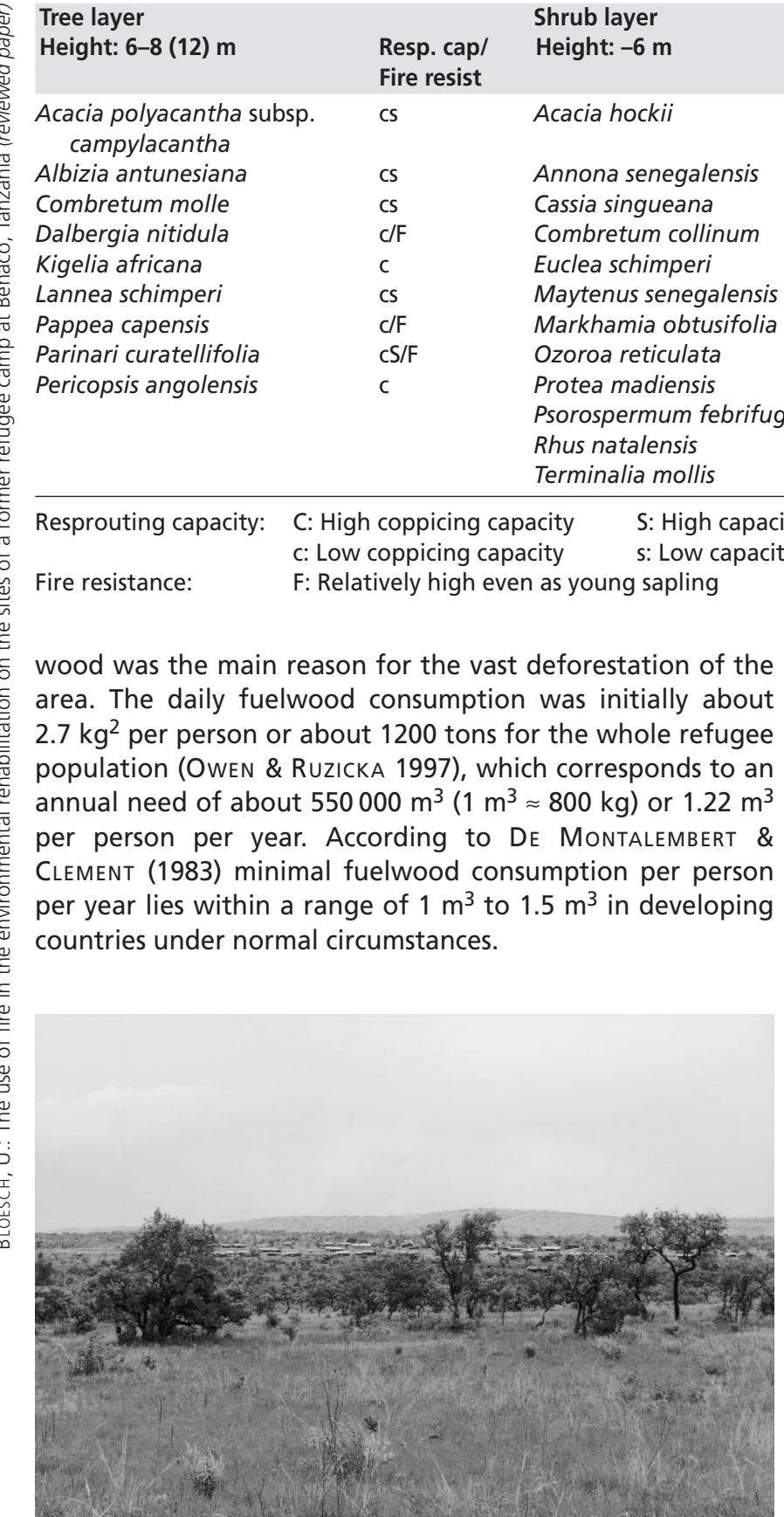

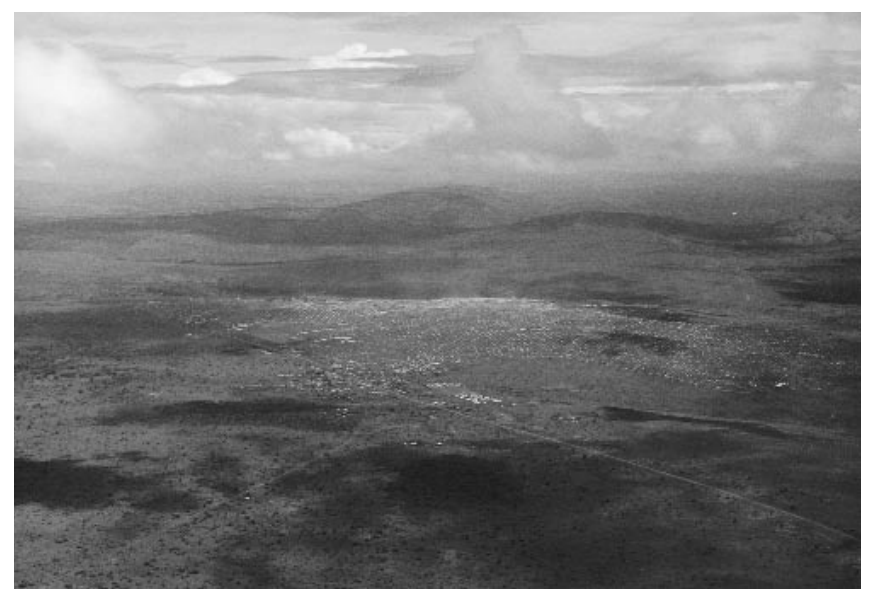

Figure 2: Figure 2a shows the village of Kasulo before the arrival of the refugees. Figure $2 b$ shows the main camp of Benaco six months after the arrival of the refugees. Kasulo is completely merged with the camp.

Abbildung 2: Abbildung 2a zeigt das Dorf Kasulo vor der Ankunft der Flüchtlinge. Abbildung $2 b$ zeigt das Hauptlager von Benaco sechs Monate nach der Ankunft der Flüchtlinge. Kasulo ist komplett verschmolzen mit dem Lager.
Due to the ever-decreasing wood resources in the vicinity of the camps and the use of energy saving methods (e.g. improved clay stoves) the daily consumption of fuelwood per person dropped significantly to $1.65 \mathrm{~kg}$ (about 580 tons for the whole population of Greater Benaco). The daily fuelwood consumption in Tanzanian villages in Kagera Region is about $1.9 \mathrm{~kg}$ per person. This similarity, however, owes more to coincidence than to any similarity in fuel supply and demand. In the Tanzanian context there are other factors influencing the increase (easy access to free wood, inefficient use of energy) and decrease (large families, fresh food, access to different pot types) in fuel consumption as compared to the refugees.

Such a tremendous demand of firewood led to severe deforestation of the surrounding savanna formations (see figure 2). Initially, a growing stock of about 50 ha was used daily to cover the fuelwood demands of all refugees! At first, dead wood was gathered in the near vicinity of the camps, but in time people would collect and cut wood within a radius of more than $10 \mathrm{~km}$. Woodcutting was selective in the early phase, i.e., people would not cut trees of low fuel quality, such as e.g., Cussonia arborea, Kigelia africana and Lannea schimperi or trees of cultural significance (Erythrina abyssinica) nor trees with large circumferences. However, in the late phase, when fuelwood became scarce, selective cutting was abandoned in the vicinities of the camps, i.e., even stumps were uprooted, thereby exposing the soil to erosion and endangering soil fertility.

The refugees left the camps after two and a half years in December 1996. An area of more than $500 \mathrm{~km}^{2}$ had been affected by extensive woodcutting. The former camp sites and their immediate surroundings were completely deforested and were partly of bare soil (risk of soil erosion). With increasing distance from the camps the degree of cutting decreased. The reduced vegetation cover in the area strongly changed the hydrology: the outflow of water sources has decreased and some open water surfaces have dried up (OXFAM ${ }^{3}$, personal communication). Fortunately, the clearfelled areas outside the campsites kept a continuous grass layer which, together with the remaining rooting system of the cut woody plants, guaranteed a minimal protection of the soil against surface erosion (mainly moderate slopes). However, frequent destructive fires endangered the natural restoration of the vegetation.

\footnotetext{
2 Fuelwood figures for Benaco based on barely-dried wood in general.

3 British non-governmental organisation, specialised in water supply and sanitation.
} 
Considering these facts it was urgent to rehabilitate the ecosystems by restoring the former tree and shrub cover which was only feasible if destructive fires were avoided. Therefore, a fire management plan was elaborated for the deforested core area (former campsites and their immediate surroundings) based on a mission done in 1997 for CARE International ${ }^{4}$. In the following we outline the approach for establishing a fire management plan.

\section{Methods}

\section{Criteria for establishing a fire management plan}

Savannas are well adapted to recurrent major natural and anthropogenic changes, which explains their generally high resilience (e.g., WALKer \& Noy-MeIR 1982; GAuslaA 1989; BLOESCH 1999). However, the resilience of savannas has its limits and there are many examples - in particular in more arid areas - where these bounds have been exceeded (WALKER \& Noy-MeIR 1982). The most striking example is the desertification of the Sahel zone in Africa.

The area of Benaco supplies many examples, which demonstrate the high resilience of the mesic Kagera savannas. The best example is the area of Nyabugombe about $15 \mathrm{~km}$ southeast of Benaco, now covered with dense savanna woodland of Acacia polyacantha subsp. campylacantha (regeneration from seed). The same area was cultivated until 1975, before people moved away and settled in an Ujamaa village (common settlement). The existence of the ruderal plants Tagetes minuta and Leonotis nepetaefolia proves that the area has been under cultivation in the past.

The restoration speed of a clearfelled savanna mainly depends on the rainfall (resilience is much higher in moist savannas than in arid ones), on the regeneration capacity of the dominating woody species and their fire resistance and also on the specific fire regime. According to SILVA (1996) tree seed that do not germinate do not survive and there is no apparent seed bank in the savanna soil. Consequently, seedling recruitment depends on current seed production, which is almost nil in a clearfelled savanna. The regeneration capacity of woody plants in a clearfelled savanna depends, therefore, on their vegetative reproductive strategy by coppice shoots and/or root suckers. The most common woody savanna plants in the area of Benaco have a high resprouting capacity, as shown by the abundance of coppice shoots and suckers of most species despite inappropriate cutting techniques (see table 1). Therefore there was no need of tree planting in the clearfelled areas outside the camps sites. In any case, large-scale tree planting is very costly and young plantations require extensive tending during the first years.

Fire is a main feature of savannas and shapes the composition, structure and distribution of plant communities. The impact on vegetation depends mainly on fire frequency, intensity and season. About $80 \%$ of the area of Benaco is burnt annually by man-made fires during the main dry season from June to August. Hot, late dry-season fires often burn large areas. Large differences in tolerance to fire exist between woody plants, whereby seedlings and saplings are most affected by fire (see also table 1). For the neighbouring Akagera National Park in Rwanda, SPINAGE \& GuInNEss (1972) reported that savanna trees are most sensitive to fire up to the $1.5 \mathrm{~m}$ stage. Trollope (1983) defined the fire-susceptible height of woody plants in an arid savanna in southeastern

${ }^{4}$ International organisation for technical co-operation and humanitarian aid.
Africa as $2 \mathrm{~m}$. Young acacias (fine-leafed) possessing protective coverings of thick corky bark are usually less affected by fire than broad-leafed trees with a sensitive regeneration.

BLOESCH (1999) outlined the characteristics of early and late dry-season fires and underlined that their impact on the vegetation is generally different. Late-burnings move faster, have a higher flame height and higher temperatures than earlyburnings and are, therefore, particularly destructive to woody plants, especially seedlings and saplings. The negative impact of late-burnings is exacerbated by the fact that savanna trees usually sprout well before the beginning of the rains and are most sensitive to fire damage at this time (INNES 1972). On the other hand, early-burnings usually only slightly scorch woody plants. SABIITI \& WEIN (1988) reported for the Queen Elizabeth National Park, Uganda that low-intensity fires (early dry-season fires) stimulate sprouting of Acacia sieberiana fourfold (no burning as reference). Cool, early dry-season fires may also activate the building of suckers of some savanna trees, as e.g., Acacia hockii. The quantities of unburned grass stubble after an early-burning also ensure minimal soil protection cover against erosion. Furthermore, burning in general may promote the germination of seed of savanna trees and shrubs such as Acacia spp. (BouxIN 1975).

\section{Fire management plan}

Any rehabilitation plan of an area has to take the former landuse by the local population and their future needs into account. Before the arrival of the refugees the small population cultivated only a small part of this area. Large parts of the savanna landscape lay fallow and were only little used, e.g. as pastures and for collecting fuelwood or medicinal plants. At the same time, however, the fallow land was an important land reserve for future generations.

Fire management is often a compromise between ecological and economic (land-use) needs and practical feasibility (RODGERS 1979). The best protection of natural woody regeneration would be to avoid any fire but this is not feasible for such a vast area, even if an immense effort were made to construct firebreaks and organise fire patrols. Following this reasoning the intervention zone was limited to the deforested core area using: a) controlled early-burning where woody regeneration of at least $1 \mathrm{~m}$ height was abundant and b) firebreaks for protecting highly fire-sensitive areas. Controlled early-burning only slightly damages natural regeneration of at least $1 \mathrm{~m}$ height and prevents a more destructive late-burning. Early-burning also facilitates a controlled burning, as the fire front advances only slowly.

In May 1997, before the beginning of the dry season and six months after the departure of the refugees, we elaborated a map for the core area of the deforestation. The following baseline data were recorded:

- degree of deforestation

- degree of regeneration (number and height of woody plants)

- areas of bare soil (risk of erosion)

- areas of tree planting and direct sowing of seed within the campsites

- roads (in view of use as natural fire-barriers)

- main relief

For the core area of deforestation, a fire management plan was defined (below), which takes two facts into consideration: a) that the operation was new for both the local population and the staff of CARE International, and b) that the proper time for early-burning and the realisation of firebreaks was short: 
- As a first priority, firebreaks were established to protect the heavily disturbed former campsites of mostly bare soil. These zones also include some young tree plantations and areas of direct sowing realised for the rehabilitation of the site which are very vulnerable to any kind of fire. The layout of the firebreaks followed natural fire-barriers as far as possible, e.g. roads, areas of bare soil or permanently wet valley bottoms. Areas of high biomass and steep slopes were avoided (rapid uphill burning increases the risk of fires crossing the firebreak). Following this concept we realised firebreaks about $30 \mathrm{~m}$ wide by controlled burning. Providing easy access by the fire brigade the width was reduced to a minimum of $10 \mathrm{~m}$.

- Areas in the vicinity of the campsites with severe deforestation but abundant woody regeneration of at least $1 \mathrm{~m}$ height were selected for a controlled early-burning. We assumed that natural regeneration of at least $1 \mathrm{~m}$ height might essentially resist a cool early-burning.

- Firebreaks alone do not guarantee the protection of firesensitive areas. In addition a fire brigade was created from amongst those people who carried out the controlled burning. Patrolling teams permanently surveyed the core area of the deforestation during the dry season when fire hazard was high. In case of an undesired fire the patrolling team would alert the entire fire brigade to extinguish the fire. Since all firemen originated from Kasulo, the local population was closely involved in the operation and this helped to improve their knowledge of controlled burning.

The controlled burning of the firebreaks and of the selected areas took place at the very beginning of the dry season, as soon as the weather conditions and moisture content of the vegetation permitted and timed to facilitate a controlled burning and minimise damage to the woody regeneration. About twenty people from Kasulo, trained in the technique of controlled burning, helped to carry out the firing. It is very important that the burning activity is well organised and guided by an expert. The following points have to be considered:

- Everybody has to know their specific task and fulfil it in a disciplined way; only one person per group is allowed to set a fire, the others are equipped with tree branches, ready to extinguish the fire where necessary (NB: branches from Euclea schimperi and Rhus natalensis are very suitable thanks to their high flame point and robust leaves).

- Rate of spread of the fire front depends mainly on following factors: a) on fuel moisture (note that at the beginning of the dry season dew levels are high early in the morning and late in the afternoon, which slows down the burning progress), b) on wind speed (variation in wind direction and velocity according to the time of day), c) on the relative air humidity and d) on the topography (see also TROLLOPE 1983).

- Low wind velocity and scarce vegetation (or moist vegetation) allows burning with the wind (except uphill burning on steep slopes); high wind velocity and dense, dry vegetation require burning against the wind.

- If the burning process is difficult to control a small strip of the vegetation has to be cut beforehand to ensure controlled burning.

- As soon as the fire catches up, it has to be extinguished opposite to the defined burning direction. The direction of the advancing fire front is guided by controlling both sides of the progressing fire front.

The realisation of the firebreaks by controlled burning is more convenient and cheaper than mechanically removing the vegetation. Controlled burning of large areas (as in our case for the protection of the woody regeneration) is easier to handle than the exact burning of the narrow firebreaks, often owing to the existence of natural fire-barriers.

\section{Results and discussion}

The fire management plan was applied to an area of about $25 \mathrm{~km}^{2}$. Controlled early-burning for the protection of the natural woody regeneration comprised an area of about 5 to $10 \mathrm{~km}^{2}$. Furthermore, about $40 \mathrm{~km}$ of firebreaks were created by controlled burning. No undesired fire occurred in the core area of the deforestation. This positive result could not have been achieved without the support of the well-trained fire brigade and the local community. Additional motivation was given to the fire brigade in the form of a promise of financial reward at the end of the dry season if no undesired fire had occurred.

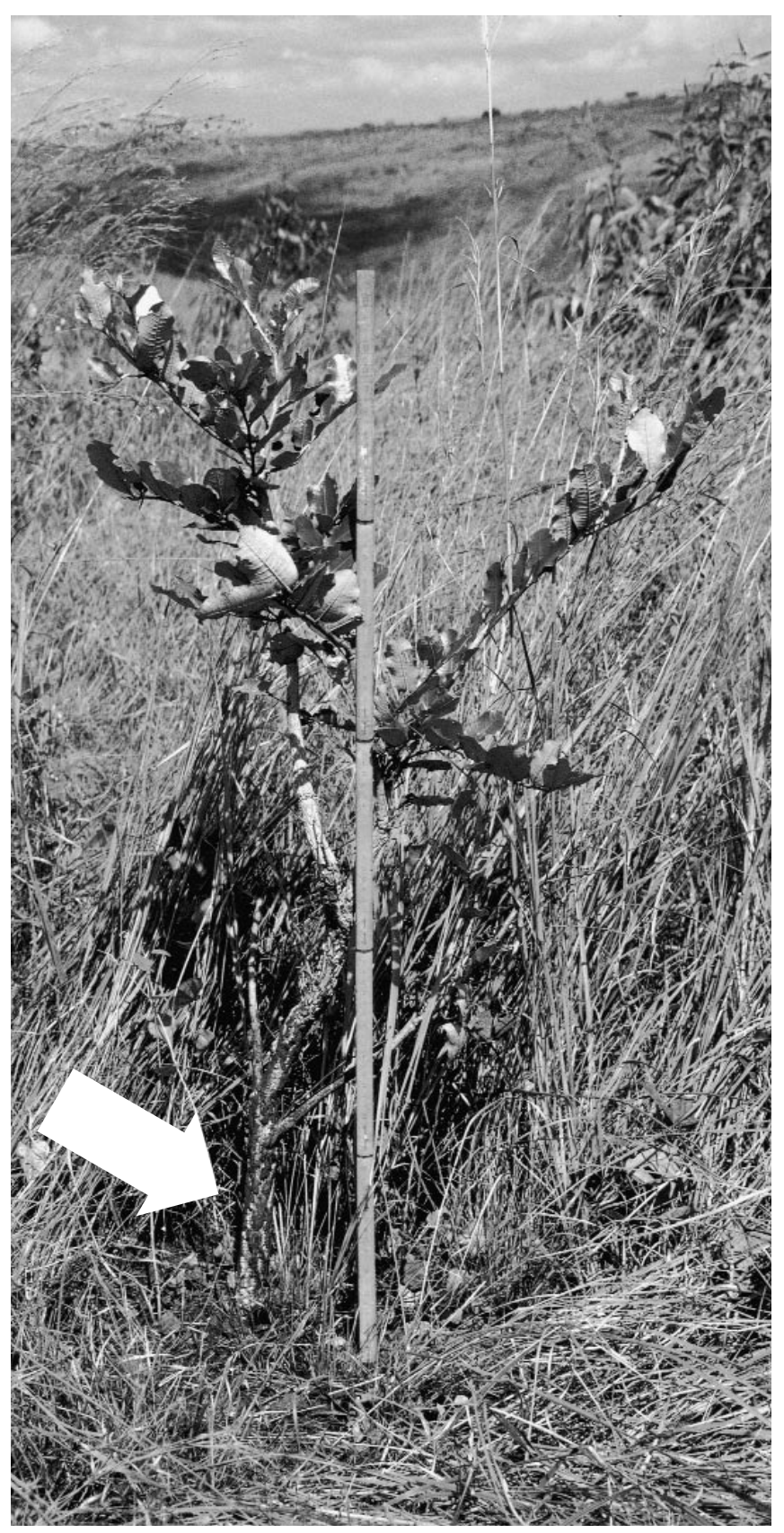

Figure 3: The burning has only scorched the bark of this young Parinari curatellifolia without harming the plant (photograph taken one year after the burning); height of the stick: $1 \mathrm{~m}$.

Abbildung 3: Das Feuer hat nur die Rinde dieses jungen Parinari curatellifolia verbrannt ohne der Pflanze zu schaden (die Fotografie wurde ein Jahr nach dem Brand gemacht); Stockhöhe: $1 \mathrm{~m}$. 
In May 1998, a rapid survey revealed further evidence of the high resilience of savanna formations and supported our hypothesis that cool burning does not - or only slightly affect regeneration of woody savanna plants of at least $1 \mathrm{~m}$ in height (see figure 3). The vigorous resprouting of the cut woody plants led to a clumped distribution of saplings and seedlings with the consequence that, within these regeneration clumps, the grass biomass was reduced and remained greener (shading effect of the woody plants) compared to the surrounding grass matrix. This vegetation mosaic led to the patchwise burning, i.e., the open areas were intensively burnt while areas with abundant woody regeneration were hardly touched by the controlled fire. Also, small regeneration (less than $1 \mathrm{~m}$ ) of Acacia hockii, Combretum collinum, Cussonia arborea, Markhamia obtusifolia and Parinari curatellifolia showed barely lethal damage. The rapid development of thick corky bark of Acacia hockii, Cussonia arborea, and Parinari curatellifolia already at a young age may have contributed to their relatively high survival rate. However, when evaluating these positive results it is important to note that during the controlled burning the fire, facilitated by a moderate wind, advanced at a steady pace. A long-lasting smouldering in the same place would have had similar destructive effects as late fires!

Unfortunately, a detailed survey, foreseen for a later date, could not be carried out. The mass migration of people and political unrest in the area of the Great Lakes led to major security problems. The local authorities, afraid of possible criminal gangs hiding in the bushes, burned the entire Benaco area in the late dry season 1998. The fierce fire destroyed most of the emerging regeneration of woody plants as well as the experimental plots installed in 1997 for monitoring the species specific reproductive strategy for different fire regimes (early-burning, late-burning and no burning). The first and preliminary encouraging data of the fire management plan could not be followed up. We had planned to continue the controlled burning for the core area for at least another two years.

The use of fire is mainly known from rangeland management with only one stakeholder. Our results, however, show that controlled burning may also be successful for the low cost rehabilitation (using natural regeneration) of clearfelled savannas (with a number of stakeholders). Controlled earlyburning may also be appropriate to protect tree plantations from destructive hot fires. In this way the yield of a plantation can be considerably increased (GAUSLAA 1989). Such a strategy, however, would require that the fire resistance to cool burning - including the fire susceptible plant height - is tested beforehand, since tree species for plantations are not usually savanna species. In view of the thousands of hectares of reforested areas seriously damaged every year in Tanzania by uncontrolled destructive fires such an approach is of considerable ecological and economic importance.

If controlled burning is applied in savanna formations we have to consider that fire is an integrated part of land-use and governed by socio-cultural traditions. Controlled burning of public land is a difficult endeavour, with numerous actors and their differing objectives, and can only be sustained if it is based on a defined and binding land-use policy, accepted by all actors. Furthermore, cool burning may also promote bush encroachment by increased resprouting at the expense of perennial grasses (see, e.g., KLÖTZLI 1980; SABIITI \& WEIN 1988), a process not suitable for every management goal (e.g. rangeland). Finally, the incident from Benaco confirms that ecological activities, which usually have long-term perspectives, can only be realised successfully if political stability prevails.

\section{Summary}

In 1994, about 450000 Rwandan refugees settled in the Greater Benaco camps in northwestern Tanzania. To meet the enormous fuelwood needs, mainly for cooking, of approx. 1200 tons per day, as well as the initial requirements for construction wood for shelter building, wood resources in the surrounding savannas were severely depleted. After repatriation and a stay of about two and a half years the refugees left behind an area of about $500 \mathrm{~km}^{2}$ affected by intense wood cutting, whereby the core area was completely deforested. The strongly reduced vegetation cover led to the depletion of the water resources and increased the risk of soil erosion. Although the resilience of these savannas is high, frequent, fierce late dry-season fires endangered the rapid natural regeneration of the woody plants. A fire management plan was set up for the highly disturbed core area. Since total fire exclusion of the vast area was not feasible, early-burning was prescribed, which is less destructive to woody regeneration than the hotter late-burning and which prevents the more destructive late dry-season fires. The techniques of controlled burning are explained. The paper pleads for the appropriate use of fire for the rehabilitation of heavily cut savannas, which takes land-use into consideration. However, it is prerequisite that all stakeholders and actors agree on the programme.

\section{Zusammenfassung}

\section{Zum Einsatz von Feuer zur ökologischen}

\section{Restauration des Flüchtlingslagers von Benaco,} Tansania

Rund 450000 rwandische Flüchtlinge waren 1994 in den Lagern von Greater Benaco untergebracht. Um ihren enormen Holzbedarf von rund 1200 Tonnen pro Tag zu decken - Holz wurde hauptsächlich als Brennmaterial zum Kochen verwendet, in der ersten Zeit aber auch als Bauholz für die Unterstände - wurden die Holzvorräte der umliegenden Savannen aufgebraucht. Als die Flüchtlinge nach rund zweieinhalb Jahren repatriiert wurden, war die Baum- und Strauchschicht auf einer Fläche von rund $500 \mathrm{~km}^{2}$ arg dezimiert und die Kernzonen im näheren Umland der Lager kahlgeschlagen. Unter der stark verminderten Vegetationsdecke trockneten Wasserstellen aus und erhöhte sich die Erosionsgefahr. Obwohl diese Savannen eine hohe Resilienz aufweisen, war die Verjüngung der Holzpflanzen durch heftige Brände bedroht, die oft gegen Ende der Trockenzeit auftreten. Daher wurde ein Feuerbewirtschaftungsplan für die stark zerstörte Kernzone ausgearbeitet. Da das Gebiet zu weitläufig ist, um Brände gänzlich ausschliessen zu können, wurde vorgeschrieben, dass zu Beginn der Trockenzeit gezielt kontrollierte Feuer eingesetzt werden sollten. Diese frühen Feuer sind wegen der tieferen Temperaturen weniger schädlich für die Baum- und Strauchverjüngung als die zerstörerischen Brände gegen Ende der Trockenzeit und sie verhindern Spätfeuer im gleichen Jahr. Im Aufsatz wird die Technik des kontrollierten Abbrennens dargelegt. Der Artikel propagiert den gezielten Einsatz von Feuer für die Restauration von übernutzten Savannen unter Berücksichtigung der Landnutzung. Voraussetzung für eine erfolgreiche Durchführung des Programms ist allerdings die Zustimmung aller Beteiligten.

\section{Résumé}

Réhabilitation environnementale à l'aide du brûlage contrôlé dans les anciens camps de réfugiés de Benaco en Tanzanie

Environ 450000 réfugiés rwandais ont été accueillis en 1994 dans les camps de Greater Benaco au nord-ouest de la Tanzanie. Afin de satisfaire leurs énormes besoins en bois de feu, 
environ 1200 t par jour utilisées surtout pour la cuisson des repas, et aussi en raison des besoins initiaux de bois pour la construction des abris, les réfugiés ont fortement exploité les savanes avoisinantes. Au moment de leur rapatriement après deux ans et demi de présence, les espèces ligneuses de la savanes étaient fortement décimées sur une zone d'environ $500 \mathrm{~km}^{2}$, les zones proche des camps étant même complètement déboisées. Le couvert végétal réduit a conduit à un épuisement des sources et a augmenté le risque d'érosion. Malgré la forte capacité de résilience écologique de ces savanes, la régénération rapide des plantes ligneuses était menacée par les feux tardifs, événement fréquent et destructeur lors de la saison sèche. En conséquence, un plan de gestion des feux a été élaboré pour la zone dévastée proche des camps. Comme l'élimination des feux dans une si vaste zone n'a pas été possible, l'utilisation du brûlage précoce contrôlé a été préconisée. Les feux précoces entraînent moins de dommages à la régénération des végétaux ligneux que les feux tardifs plus chauds, de plus ils empêchent le développement de ces derniers. Les techniques de brûlage contrôlé sont expliquées. L'article plaide pour un emploi approprié du feu dans la réhabilitation des savanes surexploitées, tout en tenant compte de I'utilisation du sol. Le soutien au programme de la part des propriétaires et des acteurs concernés reste cependant une condition préalable.

\section{References}

BLOESCH, U. (1999): Fire as a tool in the management of a savanna/ dry forest reserve in Madagascar. Appl. Veg. Sc. 2: 117-124.

BouxIN, G. (1975): Action des feux saisonniers sur la strate ligneuse dans le Parc National de l'Akagera (Rwanda, Afrique Centrale). Vegetatio 30, 3: 189-196.

De Montalembert, M.R. \& Clements, J. (1983): Fuelwood supplies in the developing countries. FAO Forestry Paper, 42, $125 \mathrm{p}$.

FAO-UNESCO (1988): FAO-Unesco Soil map of the world, revised legend. World Resources Report 60, FAO, Rome.

GAUSLAA, Y. (1989): Management and regeneration of tropical woodlands with special reference to Tanzanian conditions. A literature review. Lidia, 2: 37-112.

INNES, R.R. (1972): Fire in West African Vegetation. In: Proc. Ann. Tall Timbers Fire Ecol. Conf. 11: 147-173. Tall Timbers Res. Sta., Tallahassee.

KLöTZLI, F. (1980): Analysis of species oscillations in tropical grasslands in Tanzania due to management and weather conditions. Phytocoenologia 8(1): 13-33.

KöPPEN, W. (1931): Grundriss der Klimakunde. De Gruyter, Berlin.

OWEN, M. \& RUZICKA, I. (1997): Energy strategy for refugee-affected areas of Kagera and Kigoma areas, Tanzania. UNHCR/The European Commission, Geneva, $180 \mathrm{p}$.

RODGERS, W.A. (1979): The implications of woodland burning for wildlife management. In: AJAYI, S.S. \& HALSTEAD, L.B. (eds.): Wildlife management in savannah woodlands, Taylor \& Francis, London, pp. 151-159.

SABIITI, E.N. \& WEIN, R.W. (1988): Fire behaviour and the invasion of Acacia sieberiana into savanna grassland openings. Afr. J. Ecol. 26: 301-313.

SCientific Council for Africa South of the Sahara (1956): C.S.A. Specialist meeting on phyto-geography. Yangambi July 28 August 8, C.C.T.A./C.S.A. No 22.

SILVA, J.F. (1996): Biodiversity and stability in tropical savannas. In: Solbrig, O.T., Medina E. \& Silva, J.F. (eds.): Biodiversity and savanna ecosystem processes. Ecological Studies, vol. 121, Springer, Berlin, pp. 161-171.

SPINAGE, C.A. \& GUINNESS, F.E. (1972): Effects of fire in the Akagera National Park and Mutara Hunting Reserve, Rwanda. Rev. Zool. Bot. Afr. 86 (3-4): 301-336.

TROLLOPE, W.S.W. (1983): Control of bush-encroachment with fire in the arid savannas of southeastern Africa. PhD Thesis, University of Natal.

TroupIN, G. (1978, 1983, 1985, 1988): Flore du Rwanda. Spermatophytes. Institut National de Recherche Scientifique 18, 22, 30, 41, Butare.

WALKER, B.H. \& NOY-MEIR, I. (1982): Aspects of the stability and resilience of savanna ecosystems. In: Huntley, B.J. \& Walker, B.H. (eds.): Ecology of tropical savannas, Springer, Berlin, pp. 556-590.

Acknowledgements

We thank Erhard Stutz for editorial help. 